\title{
Effects of water aerobics on posture alignment and risk of falls of older adults: an intervention study
}

\section{Efeitos da hidroginástica no alinhamento postural e risco de quedas em idosos: um estudo de intervenção}

\author{
Efectos de los hidroginasticos sobre la alineación postural y riesgo de caídas de adultos \\ mayores: un estudio de intervención
}

\author{
Camila Costa Ibiapina Reis ${ }^{a}$ (D) , Marcos Antônio Pereira dos Santos ${ }^{b}$ (D), \\ Camila Feitosa da Costac (D), Edna Maria Silva Araújod (D), Luiz Roberto Ramos $^{\text {e* (D) }}$
}

Keywords:

Posture;

Older adult;

Risk of falls;

Water exercise.

\begin{abstract}
Considering that aging leads to losses in postural control and balance, our objective was to analyze the effects of water aerobics on posture alignment and risk of falls in older adults. A quasiexperimental intervention study included 49 older adults in the Intervention Group (IG) and 34 in the Control Group (CG). A plumbed symmetrograph assessed posture alignment, while a Time Up \& Go test determined the fall risk. The IG performed water aerobics twice a week for three months. Posture alignment significantly improved in most body segments assessed for the IG, and worsened in the CG. The low risk of falls in the IG increased by $28 \%$ in relation to the CG. We concluded that water aerobics improved posture alignment and reduced fall risk in older adults.
\end{abstract}

Palavras-chave: Postura;

Idoso; Risco de quedas; Hidroginástica.

\begin{abstract}
RESUMO
O envelhecimento leva à perdas no controle postural e no equilíbrio. O objetivo deste estudo foi analisar os efeitos da hidroginástica no alinhamento postural e no risco de quedas de idosos. Um estudo de intervenção quasi-experimental incluiu 49 idosos do Grupo Intervenção (GI) e 34 do Grupo Controle (GC). Um simetrógrafo de prumo foi usado para avaliar o alinhamento da postura e o teste Time Up \& Go para determinar o risco de quedas. O GI realizou hidroginástica, duas vezes por semana, durante três meses. Houve melhora significativa no alinhamento postural da maioria dos segmentos corporais avaliados no GI e piora no GC. O baixo risco de quedas no Gl aumentou $28 \%$ em relação ao GC. Concluímos que a hidroginástica melhorou o alinhamento postural e reduziu o risco de quedas em idosos.
\end{abstract}

Palabras clave: Alineación postural; Adulto mayor; Riesgo de caídas; Aeróbic acuático.

\begin{abstract}
RESUMEN
El envejecimiento conduce a pérdidas en el control postural y el equilibrio. El objetivo de este estudio fue analizar los efectos de los aeróbicos acuáticos sobre la alineación postural y el riesgo de caídas de los adultos mayores. Un estudio de intervención quasi-experimental incluyó a 49 adultos mayores en el Grupo de Intervención (GI) y 34 en el Grupo de Control (GC). Para evaluar la alineación de la postura se utilizó un simétrograma plomado y la prueba Time Up \& Go para determinar el riesgo de caídas. El IG realizó aeróbicos acuáticos, dos veces por semana durante tres meses. Hubo una mejora significativa en la alineación de la postura de la mayoría de los segmentos corporales evaluados en el GI y un empeoramiento en el GC. El bajo riesgo de caídas en el GI aumentó un $28 \%$ en relación al GC. Concluimos que los aeróbicos acuáticos mejoraron la alineación de la postura y redujeron el riesgo de caídas de los adultos mayores.
\end{abstract}

\footnotetext{
anniversidade Federal de São Paulo - UNIFESP, Departamento de Medicina Preventiva, Programa de Pós-graduação em Saúde Coletiva. São Paulo, SP, Brasil.

'Universidade Federal do Piauí - UFPI, Departamento de Biofísica e Fisiologia. Teresina, PI, Brasil.

'Faculdade Integral Diferencial - FACID. Teresina, PI, Brasil.

dUniversidade Federal do Piauí - UFPI, Programa de Pós-graduação em Ciências da Saúde. Teresina, PI, Brasil.

eUniversidade Federal de São Paulo - UNIFESP, Escola Paulista de Medicina, Departamento de Medicina Preventiva. São Paulo, SP, Brasil.
}

\footnotetext{
*Autor correspondente:

Luiz Roberto Ramos

E-mail: Irr@uol.com.br
} 


\section{INTRODUCTION}

Human aging process triggers a set of changes in the organism, especially in posture alignment and dynamic balance. Posture alignment involves stability and body orientation in space, while dynamic balance is an essential component for postural control, maintaining older adults in the desired body position and preventing falls (Sant'Anna et al., 2019; Pinzón Ríos, 2019; Nascimento et al., 2019; Horak, 2006).

The assessment of balance loss identified in aged individuals commonly focus on an unique and agespecific posture alignment, highlighting the presence of the following changes: rotation of the head; shoulder, scapula and pelvis elevation; internal rotation of the lower limbs; hind foot valgus; anteriorization of the head; pelvic anteversion, and knock knees (Reis et al., 2013). Cross sectional studies have demonstrated an association of physical exercise and better posture alignment and balance of the aged (Reis et al., 2012; Silva et al., 2015). In turn, an intervention study with multicomponent physical training of aged individuals showed that it can improve dynamic balance (Caldas et al., 2019).

Among all forms of physical exercises, the characteristics of water aerobics favor its practice by the aged, highlighting the following aspects: low impact on the joints, reducing the risk of muscle/joint injuries, muscle strengthening, and balance with water support, preventing falls during practice, in addition to promoting socialization, thus improving compliance. A meta-analysis of randomized trials has shown that water aerobics is associated with better functional capacity of the aged (Reichert et al., 2015).

A cross sectional study pointed to an association between water aerobics and more flexibility and muscle strength (Lima et al., 2018). Even though, a few intervention studies have assessed the benefits of water aerobics sessions on dynamic balance of the elderly, such positive results involved some methodological pitfalls, like the absence of a control group or disregarding those who did not participate in all classes (Bento et al., 2015; Souza et al., 2017). We did not find any intervention studies addressing water aerobics aiming to improve posture alignment of elders or reduce fall risk.

In this context, we conducted an intervention study with a control group to assess the effect of water aerobics sessions on two variables: posture alignment and risk of falls among the aged. We used valid methodologies to assess both outcomes, a blind assessment of both variables, before and after the intervention, aimed at treating the analysis to assess the results.

\section{METHOD}

The study population included individuals aged 60 years or more enrolled in the Third Age in Action Program (PTIA) at the Federal University of Piaui, in the second half of 2015. The PTIA promoted various physical and social activities for the aged, such as water aerobics, ballroom dance, physiotherapy, and others.

We designed a quasi-experimental intervention study to determine the effects of water aerobics sessions on posture alignment and fall risk in older adults. All the older adults enrolled in the PTIA were invited to participate in the study. We selected a convenience sample based on a total of 234 registered individuals, including those willing to attend the water aerobics classes in the intervention group (IG) first, while those attending other programs were included in the control group (CG). The following exclusion criteria were applied to a total of 142 seniors: being sick or waiting for surgery, wheelchair users, older adults who had been performing physical activity over the last months, unable to locate by phone, and refusal to participate (see flowchart below). The sample calculation indicated that to verify the effect of water aerobics classes on the parameters of posture alignment and fall risk, 90 seniors divided in two groups would be required, considering a degree of confidence of $95 \%$, error of $5 \%$, and proportion of $50 \%$. After exclusions and refusals, 92 seniors started the study (54 in the IG and 38 in the CG). Once the groups were formed, participants were referred for an assessment of posture alignment and risk of falls, performed by a researcher blind to their allocated groups.

We assessed posture alignment based on the method proposed by Kendall et al. (2007), using a posture board (symmetrograph), a rubber platform, a plumb line, a digital camera, a tripod, and a computer to analyze the photos. To classify posture alignment, scores were assigned with a plus (above the ideal) or a minus (below the ideal), with zero corresponding to the ideal posture. The scores increased with the degree of postural alteration of each body segment, individually assessed. The scores of postural changes were added together for a group score (IG and IC). A detailed description of the methodology can be found in two previous publications (Reis et al., 2012; Reis et al., 2013).

We applied a Timed Up and Go (TUG) test (Lusardi et al., 2017; Prado et al., 2017; Podsiadlo and Richardson, 1991) to assess the participants' fall risk. The dependent variable was the time to perform the sequence of movements (standing up from a chair without using the arms, walking three meters, turning around and going back), categorized according to the risk of falling (Dutra et al., 2016; Buatois, et al., 2010; Singh et al., 2015; Aveiro et al., 2012). Three categories were considered (less than 20 seconds to perform the test - low risk, 20 to 29 seconds - moderate risk, more than 30 seconds - high risk (Rosa at al., 2017).

After the assessment, only participants in the IG were participated in 50-minute water aerobics classes taught by a physical education professional, twice a week (Tuesdays and Thursdays), in the mornings, for three months. Participation frequency was regularly registered. All classes exercised the same body segments: 
foot longitudinal arch, forefoot, hindfoot, knees, pelvis, lumbar spine, thoracic spine, cervical spine, shoulders, and head. Each class was divided into stretching, warm-ups, endurance, and relaxation exercises, with 12 repetitions of each exercise, all taught by the same physical educator (see supplemental material for the detailed training protocol). The older adults with more resistance used instruments such as dumbbells and bars. All exercises were supervised by the physical educator to ensure that the participants would not exceed their own limits. After the intervention, both the IG and the CG underwent a new assessment, which was carried out by the same physiotherapist who performed the initial assessment, maintaining the same observation parameters.

Both IG and CG were not able to be have a full follow-up: five participants in the IG were not reassessed (three got sick, one refused to participate, and one traveled), while four participants in the CG could not be subjected to a new evaluation (two got sick, one without telephone contact, and one refusal). Initially, a descriptive analysis according to gender and age had been performed testing the normality of data distribution to manage the convergence of the sample mean for large samples $(n>30)$. Subsequently, Fisher's exact test and Student's t-test were applied. We used a mixed two-way ANOVA to compare the different posture measurements between IG and CG, before and after the intervention. A Wilcoxon-
Mann-Whitney test analyzed the differences before and after the intervention in the IG, and the difference between the IG and the CG in the end of the study. All individuals included in the IG who were reassessed were analyzed regardless of the number of water aerobics classes attended, to say an intention to treat analysis.

The study was approved by the Research Ethics Committee (CEP) no 581/15, of the Federal University of São Paulo. All the participants received detailed information on the nature of the investigation and signed an informed consent form.

\section{RESULTS}

Below is the flow chart (Figure 1) of inclusions and exclusions (Supplementary Material):

A total of 92 seniors started the study (54 in the IG and 38 in the CG), and 83 (49 in the IG and 34 in the CG) were reassessed after the intervention. Both groups had predominantly female participants (94\% in the IG and $80 \%$ in the CG). There were no statistically significant gender differences between the groups ( $p=0.083$, Fisher's test). Both groups had similar mean ages (67 years in the IG and 68 in the CG), while the maximum age was 94 years in the IG and 85 years in the CG. No statically significant average age differences were found between the groups ( $p=0.792, t$ test for independent samples).

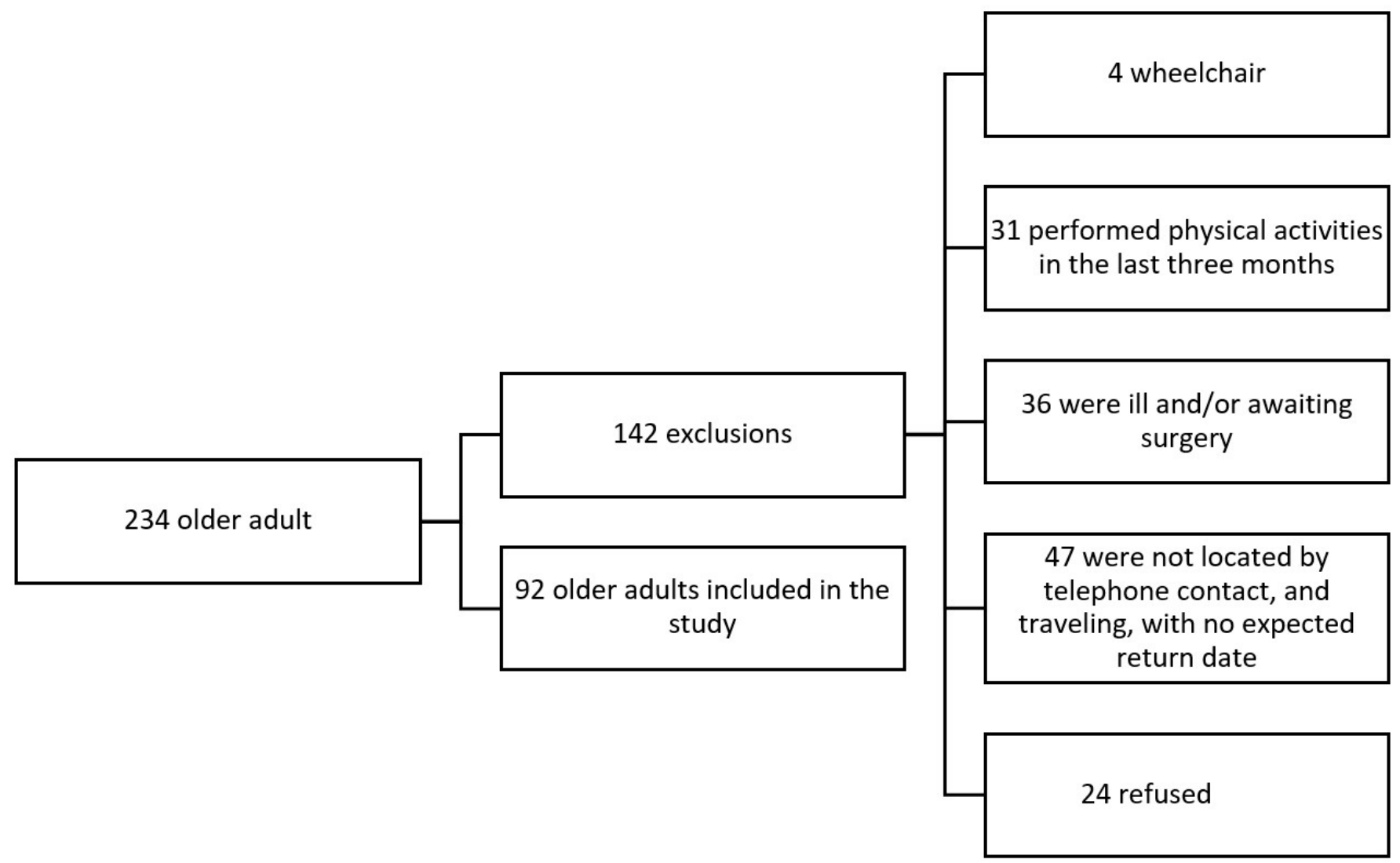

Figure 1. Final sample with inclusions and exclusions. 
In the IG, the number of classes attended varied between zero and 25 (average 16). Every senior included in the IG and reassessed after the follow-up period entered the analysis regardless of the number of water aerobics classes taken. Only $8.2 \%$ of the older adults attended $80 \%$ of classes, while most of them $53 \%$ reached an attendance from $64 \%$ to $76 \%$.

Table 1 presents the absolute values of postural changes before and after the intervention, in addition to the delta of postural changes by segment, with positive values indicating postural improvement and negative ones pointing to deterioration. It is worth mentioning that each postural change was weighted (as described in the method), in which the worse the change the higher the score value. Most of the segments assessed in the IG showed a positive delta, while seven of them showed a statistically significant improvement $(p<0.05)$ - knees $(R L, L L)$, head (AV, RL, LL), and shoulders (RL, LL). In the CG, most of the segments assessed showed a negative delta, while four segments had significantly worse results - knees (RL, LL) and shoulders (RL, LL) (Supplementary Material).
Table 2 demonstrates that before intervention, more individuals in the CG belonged to the low risk group than in the IG ( $94 \%$ and $76 \%$, respectively). After intervention, the opposite scenario emerged, as the IG had more individuals in the low risk group than the CG ( $94 \%$ and $85 \%$, respectively). Both the higher low risk and the lower moderate risk of falls in the IG were statistically significant, as well as the delta of the IG comparing with the CG (Supplementary Material).

\section{DISCUSSION}

After the intervention period with water aerobics classes, there was an overall improvement in posture alignment of most body segments assessed in the IG, with significant changes in the alignments of head, shoulders, and knees. The group of low risk of falls significantly increased, while the medium risk of falls decreased among older adults in the IG, both values proved significant in relation to the CG. Both the improvement in posture and risk of falls can be attributed to the effect of water aerobics as a controlled intervention.

Table 1. Sum of postural changes in the older adults, in the intervention (IG) and control (CG) groups, before and after the intervention with water aerobics, and the delta between the two assessments, in both groups (mixed two-way ANOVA). Teresina, PI, 2015/2016.

\begin{tabular}{|c|c|c|c|c|c|c|c|c|}
\hline \multirow{2}{*}{ Body posture } & \multicolumn{2}{|c|}{ Intervention Group } & \multirow{2}{*}{$\Delta I G$} & \multirow{2}{*}{$p$ value } & \multicolumn{2}{|c|}{ Control Group } & \multirow{2}{*}{$\Delta \mathrm{CG}$} & \multirow{2}{*}{$p$ value } \\
\hline & Before & After & & & Before & After & & \\
\hline $\begin{array}{c}\text { Foot } \\
\text { longitudinal } \\
\text { arch R AV }\end{array}$ & 41 & 39 & 2 & 0.541 & 34 & 33 & 1 & 0.579 \\
\hline $\begin{array}{c}\text { Foot } \\
\text { longitudinal } \\
\text { arch L AV }\end{array}$ & 41 & 37 & 4 & 0.236 & 34 & 33 & 1 & 0.607 \\
\hline Forefoot R AV & 35 & 32 & 3 & 0.526 & 20 & 23 & -3 & 0.243 \\
\hline Forefoot L AV & 35 & 32 & 3 & 0.526 & 20 & 23 & -3 & 0.243 \\
\hline Hindfoot R PV & 43 & 40 & 3 & 0.475 & 23 & 28 & -5 & 0.075 \\
\hline Hindfoot L PV & 43 & 43 & 0 & 0.999 & 23 & 28 & -5 & 0.055 \\
\hline Knees AV & 36 & 34 & 2 & 0.810 & 36 & 37 & -1 & 0.836 \\
\hline Knees RL & 38 & 14 & $24 *$ & 0.00002 & 21 & 34 & $-13^{*}$ & 0.024 \\
\hline Knees LL & 32 & 12 & $20 *$ & 0.002 & 19 & 31 & $-12^{*}$ & 0.003 \\
\hline Pelvis RL & 52 & 52 & 0 & 0.999 & 40 & 41 & -1 & 0.801 \\
\hline Pelvis LL & 50 & 51 & -1 & 0.861 & 41 & 41 & 0 & 0.999 \\
\hline Lumbar Spine & 41 & 41 & 0 & 0.999 & 30 & 31 & -1 & 0.801 \\
\hline Thoracic Spine & 45 & 45 & 0 & 0.999 & 44 & 45 & -1 & 0.709 \\
\hline Cervical Spine & 48 & 47 & 1 & 0.882 & 57 & 59 & -2 & 0.165 \\
\hline Head AV & 40 & 25 & $15^{*}$ & 0.0001 & 31 & 34 & -3 & 0.339 \\
\hline Head RL & 65 & 47 & $18^{*}$ & 0.003 & 44 & 44 & 0 & 0.999 \\
\hline Head LL & 64 & 48 & $16^{*}$ & 0.010 & 40 & 45 & -5 & 0.239 \\
\hline Shoulders AV & 45 & 42 & 3 & 0.217 & 34 & 34 & 0 & 0.999 \\
\hline Shoulders RL & 60 & 24 & $36^{*}$ & 0.000001 & 28 & 39 & $-11^{*}$ & 0.035 \\
\hline Shoulders LL & 46 & 24 & $22 *$ & 0.001 & 31 & 42 & $-11^{*}$ & 0.018 \\
\hline
\end{tabular}

R: right; L: left; AV: anterior view; PV: posterior view; RL: right lateral view; LL: left lateral view; $\Delta$ IG: delta before and after of the Intervention Group; $\Delta \mathrm{CG}$ : delta before and after of the Control Group. *Statically significant changes of $\Delta \mathrm{IG}$ and $\Delta \mathrm{CG}$ (Mixed two-way ANOVA) $p<0.05$. 
Table 2. Risk of falls in the older adult by control group (CG) and intervention group (IG) before and after the intervention. Teresina, PI, 2015/2016.

\begin{tabular}{|c|c|c|c|c|}
\hline \multirow{3}{*}{ Group } & \multicolumn{3}{|c|}{ Risk of falls } & \multirow{3}{*}{$\begin{array}{l}\text { Totals } \\
\mathrm{n}(\%)\end{array}$} \\
\hline & Low Risk & Medium Risk & High Risk & \\
\hline & $\mathrm{n}(\%)$ & n (\%) & $n(\%)$ & \\
\hline CG BI & 31 (93.9) & $2(6.10)$ & - & $33(100)$ \\
\hline IG BI & $37(75.5)$ & $12(24.5)$ & - & $49(100)$ \\
\hline CG Al & $28(84.8)$ & $5(15.2)$ & - & $33(100)$ \\
\hline IG Al & 46 (93.9) & $3(6.10)$ & - & 49 (100) \\
\hline IG Delta p* & 0.03 & 0.03 & - & $49(100)$ \\
\hline CG Delta p* $^{*}$ & 0.083 & 0.083 & - & $33(100)$ \\
\hline IG X CG Delta $\left(\mathrm{p}^{*}\right)$ & $<0.016$ & $<0.016$ & - & - \\
\hline
\end{tabular}

CG BI: Control Group Before Intervention; IG BI: Intervention Group Before Intervention; CG Al: Control Group After Intervention; IG AI: Intervention Group After Intervention. ${ }^{*} p$-value of the Wilcoxon test. Source: Faculty Association of the Federal University of Piauí, 2015-2016.

Our study assessed posture alignment by analyzing 20 body segments, following the principles of Kendall et al. (2007) and using a measurement methodology with a high level of interobserver agreement (Reis et al., 2013). Despite its cross-sectional nature, it has pointed to a positive association between postural alignment and physical activity (Reis et al., 2012). Other studies addressing postural assessment, such as Zambon et al. (2015), have analyzed posture alignment with an emphasis only on hip extension. It is also worth mentioning Bento and Rodacki (2015), who assessed posture alignment based on muscle strength. Our assessment shows the importance of evaluating segment by segment, making the parameters more reliable.

We assessed fall risk through the TUG test, which is highlighted for presenting a good sensitivity (87\%) and specificity (87\%) to identify the elderly at risk of falls. (Shumway-Cook et al., 2000; Buatois et al., 2010; Singh et al., 2015). Barry et al. (2014) carried out a systematic review concluding that the TUG test had limited ability to predict falls. However, in a more recent meta-analysis, Lusardi et al. (2017) found the TUG test to be a very robust functional measure to determine risk of falls among the aged. We assessed the effects of water aerobics on fall risk in older adults through a controlled intervention, which demonstrated that water aerobics significantly increased the prevalence of low fall risk in the IG.

Reichert et al. (2015) conducted a meta-analysis aimed at analyzing the effects of water aerobics practice on the functional capacity of the older adult by using randomized controlled trials. The authors concluded that water aerobics promoted a significant increase in muscle strength, flexibility, and dynamic balance in older adults, which can represent an alternative to improve functional capacity and independence at advanced age. However, we found that none of the studies in this meta-analysis addresses posture alignment or fall risk. We observed that the outcome of some intervention studies addressing water aerobics referred to a variable dynamic balance, and not fall risk, in addition to using different assessment instruments (Souza et al., 2017; Bento et al., 2015; Silva et al., 2015).

The advantage of our study is the performance of a controlled water aerobics intervention with older adults, including pre- and post-intervention assessments, based on published methodology for posture alignment (Reis et al., 2012; Reis et al., 2013) and risk of falls (Aveiro et al., 2012; Dutra et al., 2016). Additionally, the assessment was blind regarding the intervention group allocation, following a defined intervention protocol that includes a control group comparable to the intervention group and intention-to-treat analysis. However, several limitations were involved.

Our findings concern a group of older adults with access to a swimming pool (UFPI's PTIA) and cannot be extrapolated to older adults in general, specially populations without access to a swimming pool with supervised activities or living in unfavorable climatic conditions for water activities. Furthermore, the randomization of the participants was not optimal due to the urgency of including the participants in the PTIA for the water aerobics classes on the days and times scheduled. It is worth mentioning the difficulties to arrange classes of water aerobics for a number of aged individuals who needed to be committed to attend a swimming pool for three months, twice a week, to exercise in the water. Firstly, we invited the participants to the IG to ensure a minimum number of participants in the intervention, and then made inclusions in the CG. The exhaustion of the PTIA list resulted in a larger IG. Those included in the CG could have enrolled in any activity during the study, but we only followed the data on posture alignment and all risk. However, if any of the controls had engaged in physical activities that could influence posture or fall risk, the results towards the null hypothesis could have been biased. 


\section{CONCLUSION}

Comparing the scenarios before and after and the control group after the intervention, water aerobics significantly improved posture alignment and reduced the fall risk in older adults in the intervention group. Our findings suggest that the practice of water aerobics classes can improve posture alignment and decrease the risk of falls among the aged. Further intervention studies should be conducted to support public health recommendations concerning water aerobics for aged individuals to improve posture and mitigate fall risk.

\section{FUNDING}

The present study did not have any financing

\section{CONFLICTS OF INTEREST}

The authors declare no conflict of interests.

\section{REFERENCES}

Aveiro MC, Driusso P, Barham EJ, Pavarini SCL, Oishi J. Mobilidade e risco de quedas de população idosa da comunidade de São Carlos. Cien Saude Colet. 2012;17(9):2481-8. http://dx.doi.org/10.1590/S141381232012000900028. PMid:22996898.

Barry E, Galvin R, Keogh C, Horgan F, Fahey T. O teste Timed Up and Go é um preditor útil de risco de quedas em idosos residentes na comunidade: uma revisão sistemática e meta-análise. BMC Geriatr. 2014;14(1):1-14.

Bento PCB, Lopes MFA, Cebolla EC, Wolf R, Rodacki ALF. Effects of water-based training on static and dynamic balance of older women. Rejuvenation Res. 2015;18(4):326-31. http://dx.doi.org/10.1089/rej.2014.1650. PMid:25708712.

Bento PCB, Rodacki AL. Muscle function in aged women in response to a water-based exercises program and progressive resistance training. Geriatr Gerontol Int. 2015;15(11):1193-200. http://dx.doi.org/10.1111/ ggi.12418. PMid:25495858.

Buatois S, Perret-Guillaume C, Gueguen R, Miget P, Vançon $G$, Perrin $P$, et al. A simple clinical scale to stratify risk of recurrent falls in community-dwelling adults aged 65 years and olders. Phys Ther. 2010;90(4):550-60. http://dx.doi. org/10.2522/ptj.20090158. PMid:20203094.

Caldas LRR, Albuquerque MR, Araújo SR, Lopes E, Moreira AC, Cândido TM, et al. Dezesseis semanas de treinamento físico multicomponente melhoram a resistência muscular, agilidade e equilíbrio dinâmico em idosas. RBCE. 2019;41(2):150-6. http://dx.doi.org/10.1016/j. rbce.2018.04.011.

Dutra MC, Cabral ALL, Carvalho GA. Tradução para o português e validação do teste Timed Up And Go. Rev Interfaces: Saúde, Hum. Tecnol. 2016;3(9):81-8.

Horak FB. Postural orientation and equilibrium: what do we need to know about neural control of balance to prevent falls? Age Ageing. 2006;35(Suppl. 2):ii7-11. http://dx.doi. org/10.1093/ageing/afl077. PMid:16926210.
Kendall FP, McCreary EK, Provance PG, Rodgers MM, Romani WA. Músculos: provas e funções. São Paulo: Manole; 2007.

Lima PT, Malheiros KDM, Santos MR. Níveis de flexibilidade e força muscular em mulheres praticantes e não praticantes de hidroginástica. Rev Bras Ciênc Movimento. 2018;26(3):33-8.

Lusardi MM, Fritz S, Middleton A, Allison L, Wingood M, Phillips $E$, et al. Determinando o risco de quedas em adultos mais velhos que moram na comunidade: uma revisão sistemática e meta-análise usando a probabilidade pósteste. J Geriatr Phys Ther. 2017;40(1):1-36. http://dx.doi. org/10.1519/JPT.0000000000000099. PMid:27537070.

Nascimento MM, Pereira LGD, Coelho Júnior ED, Castro HD, Gomes A, Hans J. Avaliação da regulação exteroceptiva e interoceptiva do equilíbrio corporal de idosas ativas. Rev Bras Ciênc Mov. 2019;27(1):50-61.

Pinzón Ríos ID. Loss of muscle mass induced by aging. Rev Cienc Salud. 2019;17(2):223-44. http://dx.doi.org/10.12804/ revistas.urosario.edu.co/revsalud/a.7925.

Podsiadlo D, Richardson S. The timed "Up \& Go": a test of basic functional mobility for frail elderly persons. J Am Geriatr Soc. 1991;39(2):142-8. http://dx.doi. org/10.1111/j.1532-5415.1991.tb01616.x. PMid:1991946.

Prado RA, Santos KT, Reis LA, Morais KCS, Dutra AP, Porto AS. Timed Up and Go em idosos residentes na comunidade. Id on Line Rev. Mult. Psic. 2017;11(38):770-7.

Reichert T, Prado AKG, Kanitz AC, Kruel LFM. Efeitos da hidroginástica sobre a capacidade funcional de idosos: metanálise de estudos randomizados. Rev Bras Ativ Fis Saúde. 2015;20(5):447-57. http://dx.doi.org/10.12820/ rbafs.v.20n5p447.

Reis CCl, Gasparotto LPR, Kenmochi AAL, Queiroz ACV, Novais FV, Lavado EL, et al. Análise da postura corporal estática segundo o nível de atividade física em idosos residente no município de São Paulo. Rev Terapia Manual. 2012;10(49):148-55.

Reis CCl, Gasparotto LPR, Queiroz ACV, Novaes F, Lavado EL, Ramos LR. Análise do nível de concordância interobservadores na avaliação postural estática em idosos residentes no município de São Paulo. Fisioterapia Brasil. 2013;14:449-54.

Rosa AMPR, Freitas ASM, Lopes CAVS, Gonçalves SCF, Redondo ACGS, Sousa LMM. Propriedades métricas do Timed Up and Go test no idoso: revisão integrativa da literatura. Rev Invest Enferm. 2017;(1):21-31.

Sant'Anna P, Silva FO, Rodrigues ACMA, Plácido J, Ferreira $\mathrm{JV}$, Meereis ECW, et al. Posturographic analysis of older adults without dementia and patients with Alzheimer's disease: a cross-sectional study. Dement Neuropsychol. 2019;13(2):196-202. http://dx.doi.org/10.1590/198057642018dn13-020008. PMid:31285794.

Shumway-Cook A, Brauer S, Woollacott M. Predicting the probability for falls in community-dwelling older adults using the Timed Up \& Go Test. Phys Ther. 2000;80(9):896-903. http://dx.doi.org/10.1093/ptj/80.9.896. PMid:10960937.

Silva GR, Terra GDSV, Tavares MR, Neiva CM, Rodrigues CAC, Martins DW, et al. Idosos praticantes e não praticantes de 
exercícios físicos: uma comparação do estado de equilíbrio. Rev Kairós. 2015;18(2):311-26.

Singh DKA, Pillai SGK, Shahar S, Tan ST, Tai CC. Association between physiological falls risk and physical performance tests among community dwelling older adults. Clin Interv Aging. 2015;10:1319-26. http://dx.doi.org/10.2147/CIA. S79398. PMid:26316727.
Souza RO Jr, Deprá PP, Silveira AM. Efeitos da hidroginástica com exercícios dinâmicos em deslocamento sobre o equilíbrio corporal de idosos. Fisioter Pesqui. 2017;24(3):303-10. http://dx.doi.org/10.1590/1809-2950/16906724032017.

Zambon TB, Gonelli PRG, Gonçalves RD, Borges BLA, Montebelo MIL, Cesar MC. Análise comparativa da flexibilidade de mulheres idosas ativas e não ativas. Acta Fisiátr. 2015;22(1):14-8. 


\section{SUPPLEMENTARY MATERIAL}

SUPPLEMENTARY MATERIAL ACCOMPANIES THIS PAPER.

Supplementary material - annex I

This material is available as part of the online article from https://www.scielo.br/j/rbce 